\title{
Determination of Element Levels of Lagoon from Townships near Cocody City Abidjan Côte D'Ivoire Using Energy Dispersive X-Ray Fluorescence
}

\author{
Alfred Djoman Djama Agbo ${ }^{1 *}$, Koudou Djagouri ${ }^{1,2}$, Jean-Claude Olkalé Brigui1, \\ Konin Pierre-Claver Kakou ${ }^{1}$ \\ ${ }^{1}$ Faculty of Sciences of Structure of Matter and Technology, Laboratory of Matter Sciences of Environment and Solar \\ Energy, University Felix Houphouet-Boigny of Cocody, Abidjan, Côte d'Ivoire \\ ${ }^{2}$ Department of Sciences and Technology, Ecole Normale Supérieure, Abidjan, Côte d'Ivoire \\ Email:djamaalfred@gmail.com, lazouri06@gmail.com,briguiolkale@gmail.com,koninclaver@gmail.com
}

How to cite this paper: Agbo, A.D.D., Djagouri, K., Brigui, J.-C.O. and Kakou, K.P.-C. (2021) Determination of Element Levels of Lagoon from Townships near Cocody City Abidjan Côte D'Ivoire Using Energy Dispersive X-Ray Fluorescence. World Journal of Nuclear Science and Technology, 11, 109-118.

https://doi.org/10.4236/wjnst.2021.112008

Received: February 1, 2021

Accepted: April 9, 2021

Published: April 12, 2021

Copyright $\odot 2021$ by author(s) and Scientific Research Publishing Inc. This work is licensed under the Creative Commons Attribution International License (CC BY 4.0).

http://creativecommons.org/licenses/by/4.0/

\begin{abstract}
Eight water bottles from Ebrie lagoon with pollution potency were studied using nuclear chemistry technique and Energy dispersive X-ray fluorescence. This pollution is characterized by $\mathrm{pH}$ and conductivity parameters, concentrations average in $\mathrm{mg} / \mathrm{L}$ of metals such Fe (0.731), $\mathrm{Mn}$ (0.345), $\mathrm{Cr}(0.070), \mathrm{Cu}$ (0.014) and concentrations of nutrients known to be pollutants and toxic for living organisms. These heavy metals are dangerous to the lives, the local inhabitants and also a threat to aquatic life since this water is essential for the economical town, Abidjan. According to the Manganese concentration average $(0.345 \mathrm{mg})$ values that higher than WHO $(0.05 \mathrm{mg})$ value, the main likely source of pollutants is anthropogenic, industrial and agricultural. This study also shows the use of materials and lubricants near the lagoon that pollute this water.
\end{abstract}

\section{Keywords}

Ebrie Lagoon, Pollution, Heavy Metals, Energy Dispersive X-Ray Fluorescence

\section{Introduction}

Abidjan region has experienced rapid demographic development since 1960. This population growth is accompanied by an intensification of port and industrial activities, which is not correlated with the installation of efficient and adequate sanitation structures. Most domestic and industrial wastewater is dis- 
charged into the Ebrie Lagoon without any prior treatment; which leads to a deterioration of the biotopes and a disappearance of certain species with stable physicochemical characteristics (a community of living beings or biocenosis) and the appearance of new species that support polluted environments [1]. As a result, fish and shell fish, waterfowl, and freshwater and marine mammals may accumulate hazardous concentrations of toxic chemicals [2]. This pollution results also in the death of marine fauna: dead fish, shellfish and unconscious oysters, poor water status (sea, lagoons, lake, ...) but above all an impact on the health of populations in general and in particular those living in the vicinity of these waters. Previous studies showed that heavy metals such as manganese, mercury, arsenic, lead, iron and mercury at a certain level of concentration are considered to be harmful to human health. The heavy metals play a vital role in the normal functioning of human body. Inefficiency of one of the heavy elements will disrupt the normal functioning of human beings. Heavy metals also come from natural and artificial water sources. These chemical elements can be toxic and therefore dangerous for humans. Some studies have shown that the main sources of heavy metals are industrial wastes from mining sites, manufacturing and metal finishing plants, domestic waste water and run off from roads. They pose a threat when they are in surface water and groundwater. Some heavy metals such as $\mathrm{Hg}, \mathrm{Pb}, \mathrm{As}, \mathrm{Cd}, \mathrm{Fe}, \mathrm{Co}, \mathrm{Mn}, \mathrm{Cr}$ etc., have been identified as harmful to the aquatic ecosystem and human health [3].

In this work, we focused to study lagoon Ebrie pollution by determination of the concentrations levels of the heavy metals, chemical components likely to pollute that water. This study is carried out by Energy dispersive X-ray Fluorescence technique.

\section{Materials and Methods}

On the various sites that are M'Badon, M'Pouto, Blokhauss and Cocody village (Figure 1), Polyethylene (PE) bottles previously washed well, rinsed with nitric acid and labeled, polyethylene gallons, were used to take samples at about $20 \mathrm{~cm}$ deep at each site, $1 \mathrm{~L}$ of sample to fill the one-liter bottle in September 2018. Samples and the addition of $4 \mathrm{ml}$ of nitric acid $\left(\mathrm{HNO}_{3}\right)$ 65\% are made in situ. The bottles were filled to the brim without any space to prevent the entrapment of gases that could alter the chemical properties of the water. The bottles were well covered with lids and appropriately labeled we kept all the water samples in the pre-cleaned PE bottles in an ice chest and carry them to store in a refrigerator.

A $\mathrm{pH}$ meter and a conductivity meter were used to measure the physico-chemical parameters of the water, i.e. $\mathrm{pH}$, conductivity and temperature at the site. The devices were HANNA brand with the following features: automatic calibration, self-extinction with a pH range of [2 - $16 \pm 0.01]$ thermometer range $\left[5^{\circ} \mathrm{C}-60^{\circ} \mathrm{C}\right]$. The ED-XRF spectrometer used in this study consisted of an X-ray generator as the excitation source operated at $45 \mathrm{~V} / 5 \mathrm{~mA}$; Canberra $\mathrm{Si}$ (Li) detector, an ORTEC spectroscopy shaping amplifier model 571, ORTEC high voltage 


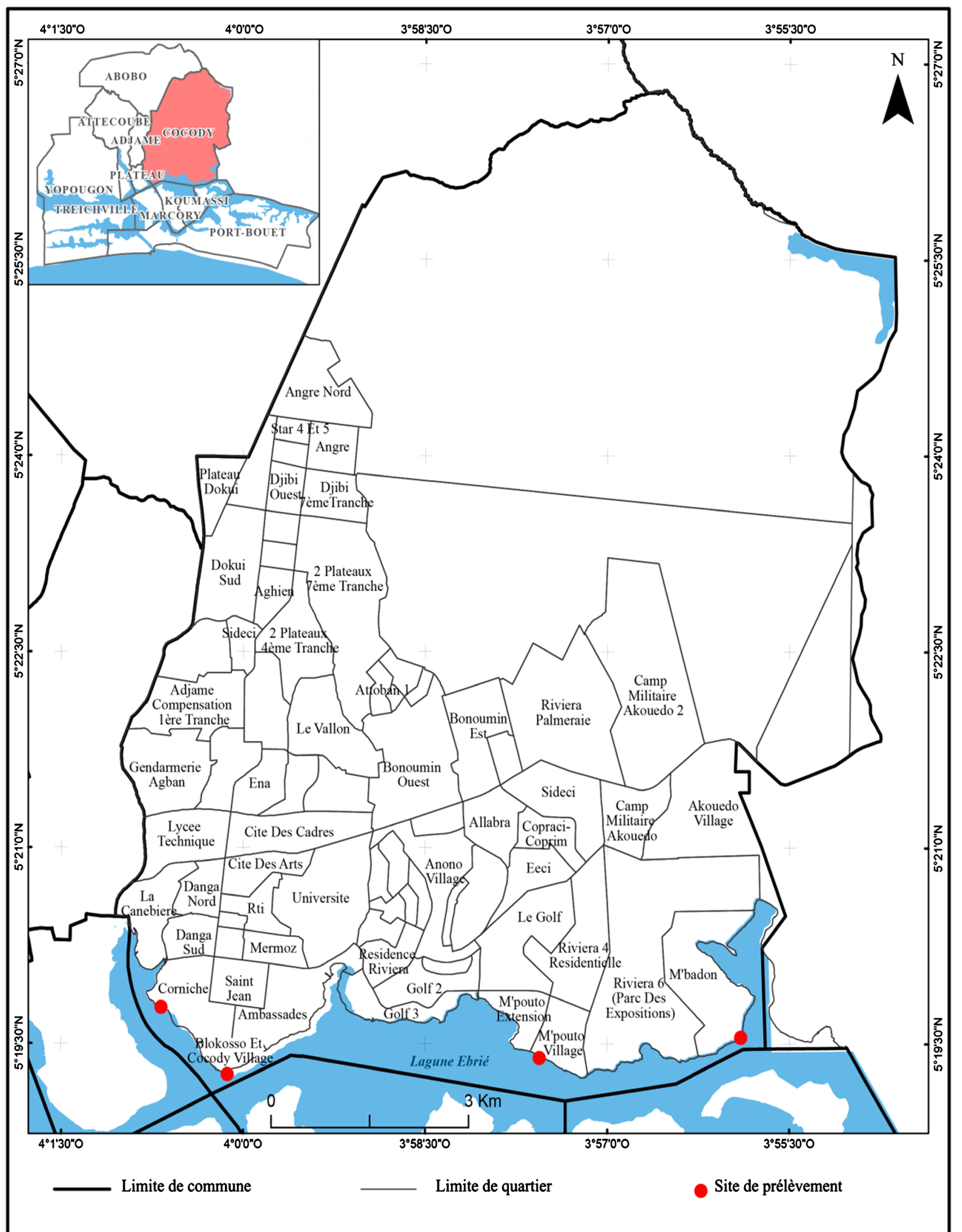

Sources: CNTIG,2012; Enquêtes de terrain, 2019

Réalisation: KOUADIO, 2019

Figure 1. Samples sites in red points. 


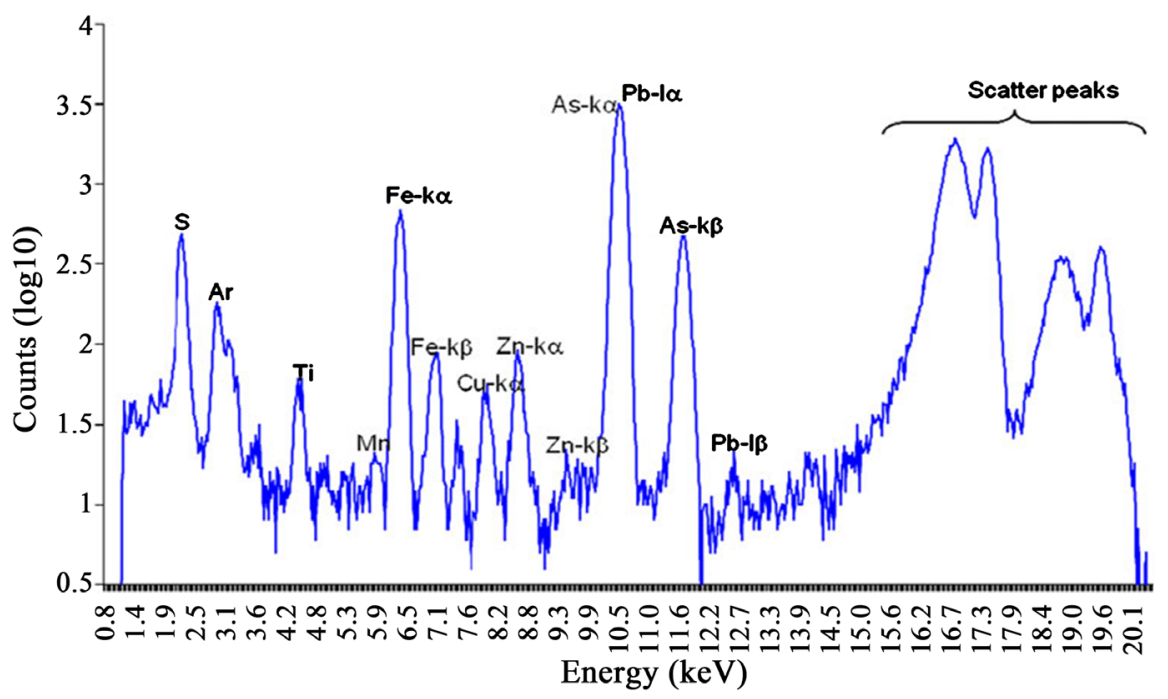

Figure 2. A water sample spectrum.

supply bias model 475 , ORTEC liquid nitrogen monitor and a Canberra multichannel analyzer (S-100) interfaced with a 486 channel personal computer. Nonlinear least squares fitting of the AXIL software program was used for the spectrum deconvolution (Figure 2) [4]. Chemical method used also for the determination of nutrients concentrations.

\section{Results and Discussions}

An important indicator of water quality is $\mathrm{pH}$. It is a measure of the acidity of a chemical solution. Acid base reactions are important in seawater, lagoon water because of their influence on $\mathrm{pH}$ and the ion chemistry. The $\mathrm{pH}$ value in the study area varies between 7.37 and 7.80 (Table 1 ), these $\mathrm{pH}$ values are probably caused by agricultural and domestic activities using a lot of fertilizer.

Iron element is the most available metal on earth. This metallic element inhibits the growth of bacteria in groundwater [5]. The iron content of the water sample is also within the permissible limit of WHO $(1.0 \mathrm{mg} / \mathrm{L})$. Iron concentration (Figure 3) of the lagoon water sample has maximum value of $0.796 \mathrm{mg} / \mathrm{L}$ at Cocody village and minimum of $0.658 \mathrm{mg} / \mathrm{L}$ at M'badon. The level of iron could be the result of clay deposits in the area. The presence of iron is characterized by the red color of the water when it is left to stand for a few minutes [6]. The high values of conductivity $2777 \mu \mathrm{S} / \mathrm{cm}$ and $1192 \mu \mathrm{S} / \mathrm{cm}$ (Table 1) can explain the high levels of Iron in Blokosso and Corniche stations respectively $0.746 \mathrm{mg} / \mathrm{L}$ and $0.796 \mathrm{mg} / \mathrm{L}$.

In Figure 4, manganese values are more than the permissible limit of WHO $(0.05 \mathrm{mg} / \mathrm{L})$. In this study, the manganese content in the lagoon water samples was estimated to be the level of $0.368 \mathrm{mg} / \mathrm{L}$ maximun at Blokosso and 0.318 $\mathrm{mg} / \mathrm{L}$ minimum at M'pouto. The study of Senthil [7] on the influence of domestic waste, natural geological rocks and industrial effluent can explain high levels of manganese on stations. So, the high values of $\mathrm{Mn}$ are probably caused by the 
industrial wastes.

In September 2018, the total copper concentration (Figure 5) in the Ebrie lagoon samples recorded the highest value of $0.014 \mathrm{mg} / \mathrm{L}$ at Blokosso and others stations copper contents are less than $0.003 \mathrm{mg} / \mathrm{L}$. The permissible limit (WHO

Table 1. Physico-chemical parameters.

\begin{tabular}{ccccc}
\hline Sites & Blokosso & Cocody village & M'badon & M'pouto \\
\hline $\mathrm{Ph}$ & 7.81 & 7.37 & 7.59 & 7.69 \\
Temperature $\left({ }^{\circ} \mathrm{C}\right)$ & 26.8 & 26.8 & 26.8 & 26.8 \\
Conductivity $(\mu \mathrm{S} / \mathrm{m})$ & 2777 & 1192 & 344 & 359 \\
\hline
\end{tabular}

Table 2. Results of physical parameters and nutrients tests, metals concentrations.

\begin{tabular}{|c|c|c|c|c|c|c|}
\hline Trace metals & & Blokosso & $\begin{array}{l}\text { Cocody } \\
\text { village }\end{array}$ & M'badon & M'pouto & $\begin{array}{c}\text { WHO (Guidelines } \\
\text { values for effluent } \\
\text { water) }\end{array}$ \\
\hline Total Iron (Fe) & $\mathrm{mg} / \mathrm{L}$ & 0.746 & 0.796 & 0.658 & 0.724 & 1 \\
\hline Total Manganese (Mn) & $\mathrm{mg} / \mathrm{L}$ & 0.368 & 0.340 & 0.356 & 0.318 & 0.05 \\
\hline Total copper $(\mathrm{Cu})$ & $\mathrm{mg} / \mathrm{L}$ & 0.014 & $<0.003$ & $<0.003$ & $<0.003$ & 2.5 \\
\hline Total Zinc (Zn) & $\mathrm{mg} / \mathrm{L}$ & $<0.001$ & $<0.001$ & $<0.001$ & $<0.001$ & 3 \\
\hline Total Chromium (Cr) & $\mathrm{mg} / \mathrm{L}$ & 0.130 & 0.020 & 0.076 & 0.056 & 0.5 \\
\hline Total Magnesium (Mg) & $\mathrm{mg} / \mathrm{L}$ & 2.504 & 1.178 & 0.600 & 0.500 & 150 \\
\hline Total Lead (Pb) & $\mathrm{mg} / \mathrm{L}$ & $<0.001$ & $<0.001$ & $<0.001$ & $<0.001$ & 0.5 \\
\hline Total Arsenic (As) & $\mathrm{mg} / \mathrm{L}$ & $<0.001$ & $<0.001$ & $<0.001$ & $<0.001$ & 0.1 \\
\hline Mercury (Hg) & $\mathrm{mg} / \mathrm{L}$ & $<0.001$ & $<0.001$ & $<0.001$ & $<0.001$ & 0.005 \\
\hline \multicolumn{7}{|l|}{ Nutrients } \\
\hline Nitrate & $\mathrm{mg} / \mathrm{L}$ & 16.475 & 0.845 & 0.795 & 1.05 & 10 \\
\hline Phosphate & $\mathrm{mg} / \mathrm{L}$ & 9.720 & 5.962 & 8.381 & 2.416 & 5 \\
\hline Sulphate & $\mathrm{mg} / \mathrm{L}$ & 109.975 & 140.689 & 102.117 & 42.12 & 250 \\
\hline
\end{tabular}

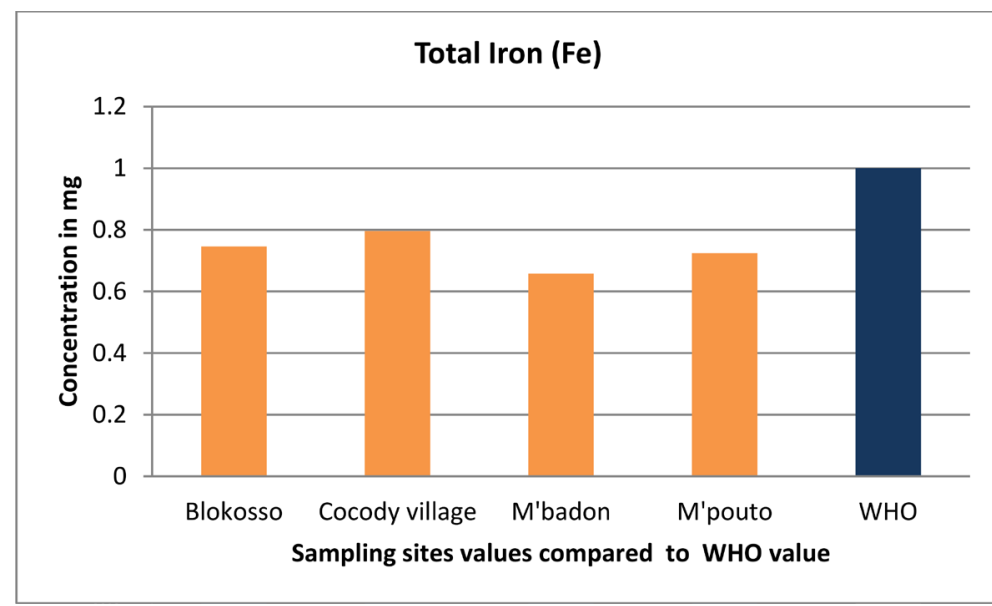

Figure 3. Iron concentration in studied sites. 


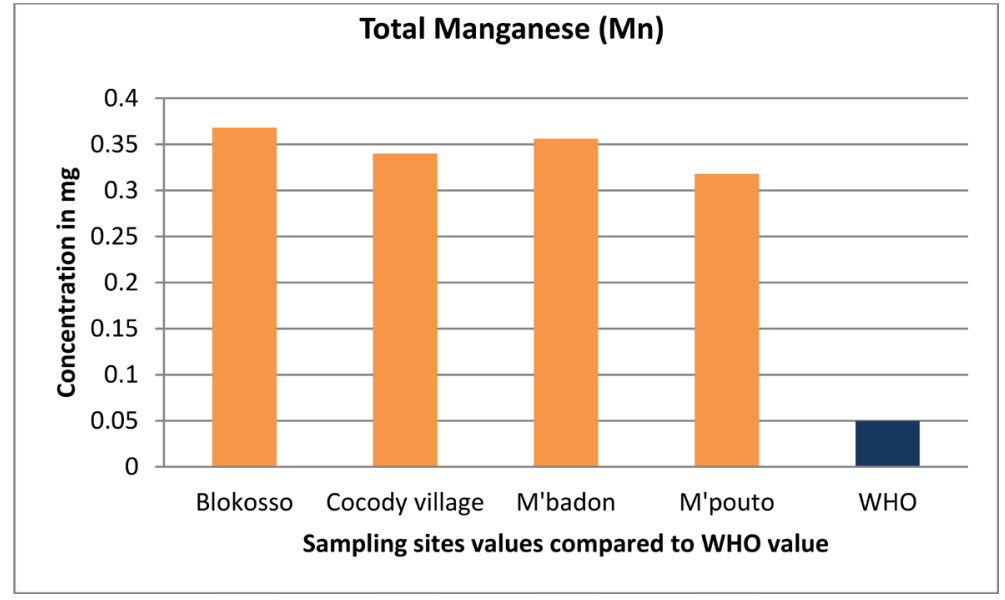

Figure 4. Manganese concentration in studied sites.

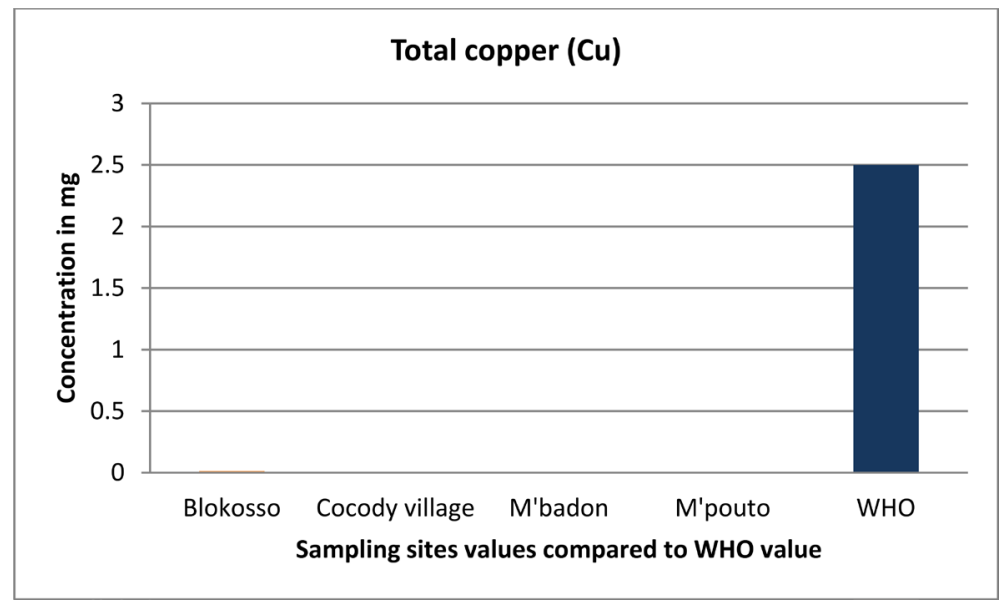

Figure 5. Copper concentration in studied sites.

permissible limit of Copper is $2.5 \mathrm{mg} / \mathrm{L}$ ) [8]. The source of copper in this water may be due to the dumping of industrial and domestic wastes. Corrosion of brass and copper pipes also contribute to copper level in water. The studies of Rao [9]. showed that the alkaline $\mathrm{pH}$ of the medium can also be the cause of low level of copper, as heavy metals are precipitated as their salts at high $\mathrm{pH}$ and are deposited as sediments

In Figure 6, Chromium is present in small quantities in nature. It is maximum present in rocks than in those of silica type. Chromium in its physico-chemical form is a toxic element well-known [10]. In the present study, chromium was found to be maximum of $0.130 \mathrm{mg} / \mathrm{L}$ at Blokosso. The chromium level above the WHO limit could pose a threat to human health in these localities. The presence of chromium in soaps and detergents used for washing and bathing by villagers near Ebrie lagoon could be responsible for the chromium level in these samples [11]. Magnesium concentration is higher to Blokosso site $(2.504 \mathrm{mg} / \mathrm{L}), 1.178 \mathrm{mg} / \mathrm{L}$ at Cocody village, $0.600 \mathrm{mg} / \mathrm{L}$ and finally $0.500 \mathrm{mg} / \mathrm{L}$ in M'pouto (Figure 7).

The works of Grober [12] showed that vegetables, nuts, seeds, and unprocessed 


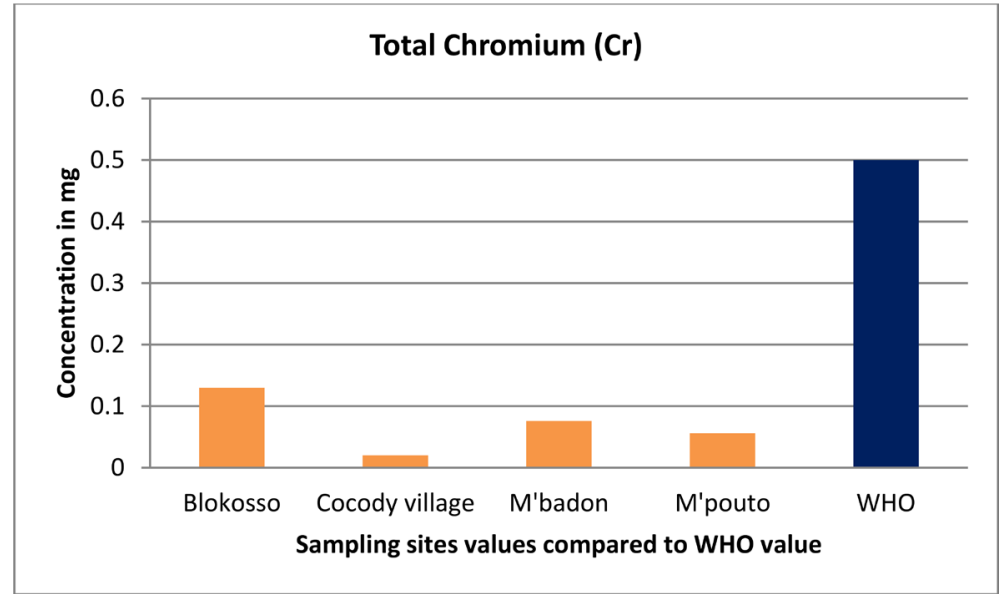

Figure 6. Chromium concentration in studied sites.

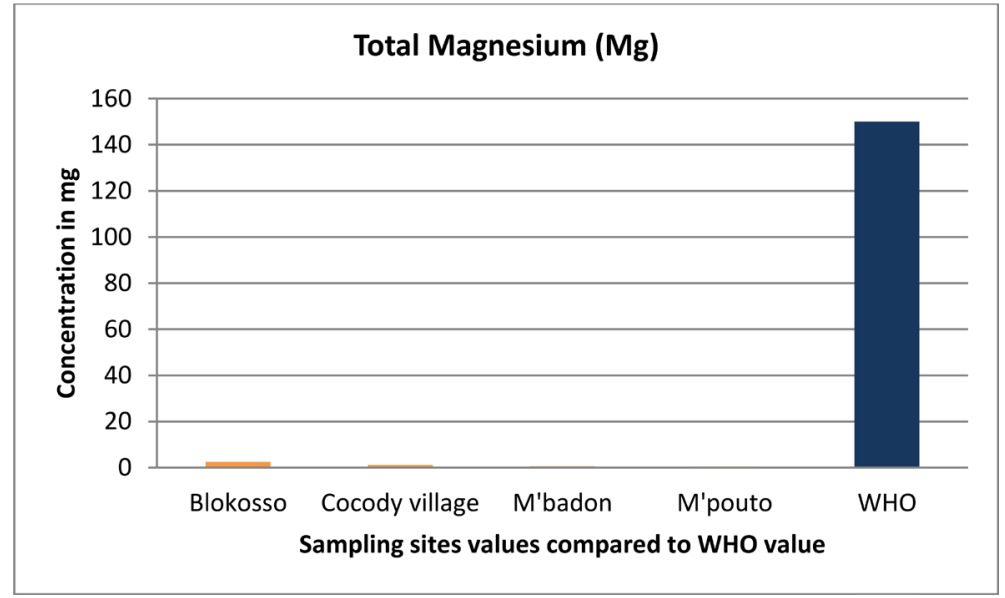

Figure 7. Magnesium concentration in studied sites.

cereals are sources of magnesium. Its presence in this water may be due to factory waste dumped in lagoon. The heavy metals well known as toxics are arsenic, lead and mercury. Their $0.001 \mathrm{mg} / \mathrm{L}$ values are less than $0.01 \mathrm{mg} / \mathrm{L}(<0.001$ $\mathrm{mg} / \mathrm{L})$.

About nutrients tests, at the Blokosso site, the nitrate concentration in Figure 8 is $16.475 \mathrm{mg} / \mathrm{L}$, it is the most important value on the stations. The limit permissible value from WHO is $10 \mathrm{mg} / \mathrm{L}$. The presence of nitrate is due to agricultural activities [13].

The phosphate concentrations (Figure 9) are $9.720 \mathrm{mg} / \mathrm{L}$ at Blokosso station, $8.381 \mathrm{mg} / \mathrm{L}$ at M'badon $\mathrm{mg} / \mathrm{L}, 5.962 \mathrm{mg} / \mathrm{L}$ and $2.416 \mathrm{mg} / \mathrm{L}$ in M'pouto station. The limit permissible is $5 \mathrm{mg} / \mathrm{L}$. Aquatic plants feed on inorganic phosphate, usually in the form of orthophosphate ions $\left(\mathrm{PO}_{4}^{3-}\right)$. Agricultural activities on the banks of the Ebrié lagoon may explain the presence of this nutrient in this water. The high level of phosphate at Blokosso station (Table 2) is probably due to level of iron in this site [14].

The sulphate concentration varies from minimum $42.12 \mathrm{mg}$ in M'pouto to $109.975 \mathrm{mg}$ maximum at Cocody village (Figure 10). Potassium, ammonium 


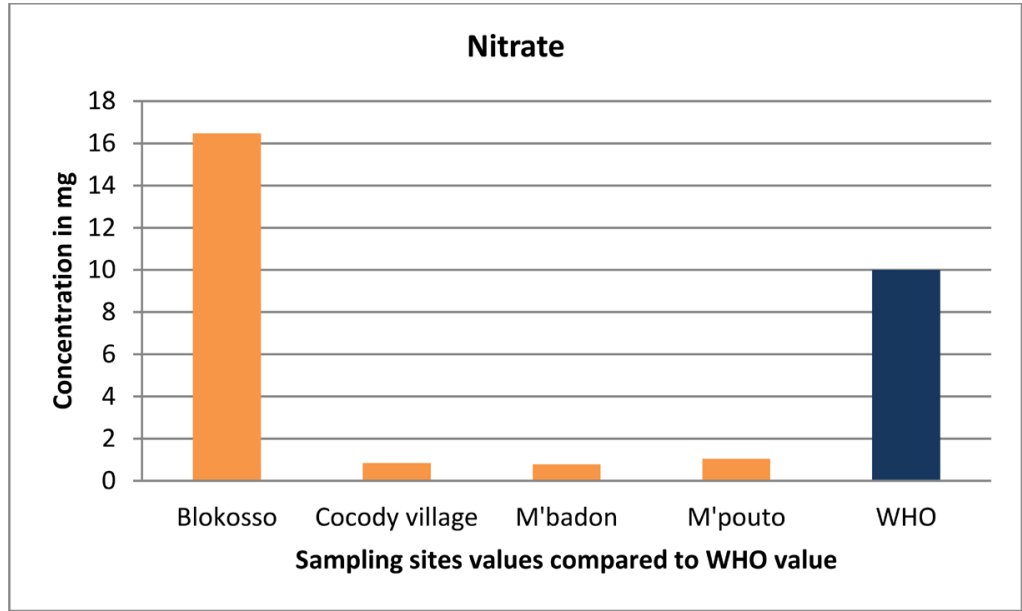

Figure 8. Nitrate concentration in studied sites.

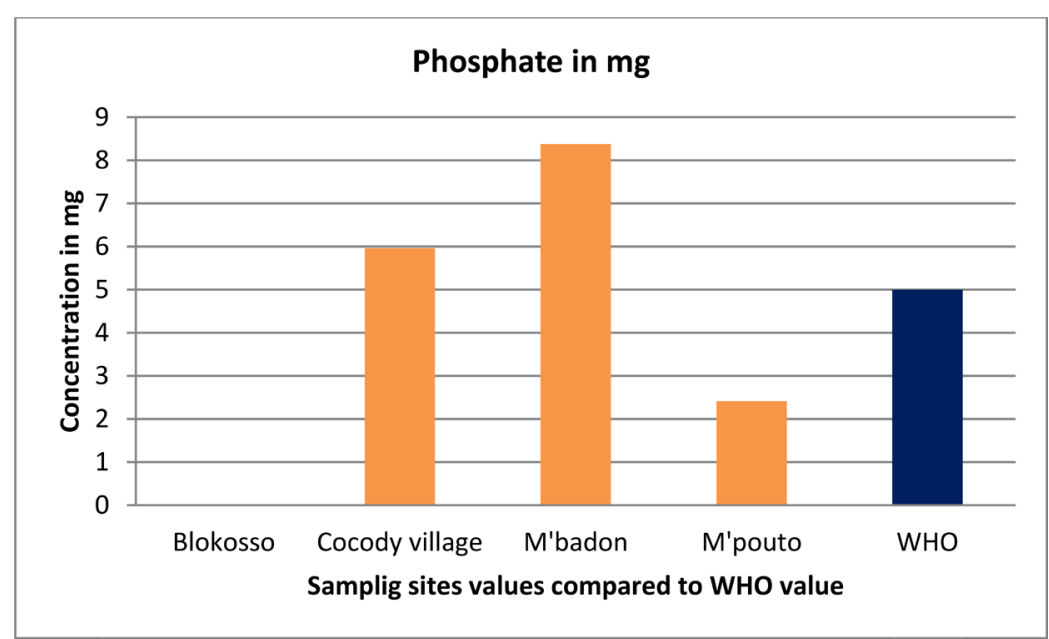

Figure 9. Phosphate concentration in studied sites.

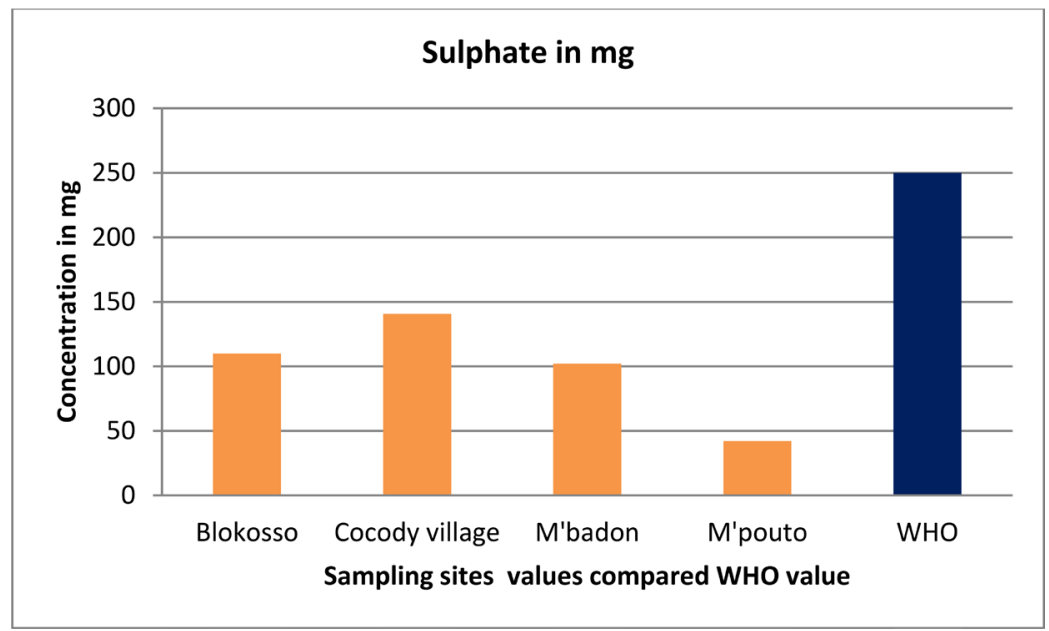

Figure 10. Sulphate concentration in studied sites.

and magnesium sulphates are used in fertilisers for agricultural activities and that is contributed to pollute the lagoon Ebrie. 


\section{Conclusion}

This study is performed with nuclear technology ED-X-ray fluorescence technique which showed that the sources of the pollutants are anthropogenic, probably arising from industrial, agricultural activities, materials and lubricants used near the lagoon. We note the insignificant values of $\mathrm{Pb}$, As, $\mathrm{Hg}$, metals well known as toxics, in that water, near from villages, Blokosso, Cocody village, M'badon and M'pouto. One of the main causes of pollution in this environment is industrial according to the Mn concentration values that are higher than $\mathrm{WHO}$ value. The purpose of this work is to prevent the populations using this water from human poisoning. The nutrients such as sulphate, magnesium, nitrate and phosphate used as fertilisers for agricultural activities, contribute to increasing the level of pollution of the Lagoon Ebrie.

\section{Acknowledgements}

The authors wish to thank the University Felix Houphouet-Boigny of Cocody for its contribution. Especially to Nuclear physical Environmental Research Group.

\section{Conflicts of Interest}

The authors declare no conflicts of interest regarding the publication of this paper.

\section{References}

[1] Adingra, A.A. and Kouassi, A.M. (2011) Pollution en Lagune Ebrié et ses impacts sur l'environnement et les populations riveraines. F. Tech. \& Doc. Vulg, 48-53.

[2] Begum, A., HariKrishna, S. and Khan, I. (2009) Analysis of Heavy Metals in Water, Sediments and Fish Samples of Madivala Lakes of Bangalore Karnatak. International Journal of Chem Tech Research, 1, 245-249.

[3] Abdulrafiu, M.O. (2011) Quality Assessment of Groundwater in the Vicinity of Dumpsites in Ifo and Lagos, Southwestern Nigeria. Advances in Applied Science Research, 2, 289-298.

[4] IAEA (2005) Quantitative X-Ray Analysis System. http://www.iaea.org/OurWork/ST/NA/NAAL/pci/ins/xrf/.../QXAS Manual.pdf

[5] Moscow, S., Jothivenkatachalam, K. and Subramani, P. (2011) Agricultural Activities Impact on Groundwater of Cauvery River Belt in Papanasam Taluk, Tamilnadu, India. Der Chemica Sinica, 2, 199-206.

[6] Elinge, C.M., Itodo, A.U., Peni, I.J., Birnin-Yauri, U.A. and Mbongo, A.N. (2011) Assessment of Heavy Metals Concentrations in Bore-Hole Waters in Aliero Community of Kebbi State. Advances in Applied Science Research, 2, 279-282.

[7] Senthilkumar, R.D., Narayanaswamy, R. and Ramakrishnan, K. (2001) Studies on Heavy Metal Pollution of Ground Water in and around Trichy Town, Tamilnadu, India. Pollution Research, 20, 93-97.

[8] WHO (World Health Organisation) (2004) Guidelines for Drinking-Water Quality. 4th Edition. 
[9] Rao, L.M. and Manjula Sree Patnaik, R. (2000) Heavy Metal Accumulation in the Cat Fish Mystusvitatus (Bloch) from Mehadrigededda Stream of Visakapatanam, India. Pollution Research, 19, 325-329.

[10] Elhoussine, D. (2009) Impact of Urban Waste Waters on Groundwater Quality in the Water Shed of Middle Sebou. Journal of the Black Sea, 15, 157-164.

[11] Iqbal, M.A. and Gupta, S.G. (2009) Studies on Heavy Metal Ion Pollution of Ground Water Sources as an Effect of Municipal Solid Waste Dumping. African Journal of Basic \& Applied Sciences, 1, 117-122.

[12] Grober, U., Schmidt, J. and Kisters, K. (2015) Magnesium in Prevention and Therapy. Nutrients, 7, 8199-8226. https://doi.org/10.3390/nu7095388

[13] WHO (World Health Organization) (2018) Management of Radioactivity in Drinking-Water. $124 \mathrm{p}$.

[14] (2004) Canadian Water Quality Guidelines for the Protection of Aquatic Life. 